\title{
Penguatan Usaha Mikro dengan Sistem Bagi Hasil Bersama LSM di Desa Kertasari, Kabupaten Sumbawa Barat, Nusa Tenggara Barat
}

\author{
Satria Arif Budiman', Ida Ansharyani², Eni Hidayati*3, Niechi Valentino ${ }^{4}$, \\ 1,2Komunitas Penjaga Pulau, Jalan Kebayan, Sumbawa Besar, Indonesia \\ 3,4Prodi Kehutanan, Fakultas Pertanian, Universitas Mataram, Jalan Majapahit 62, Mataram, Indonesia. \\ *email: eni.hidayati@unram.ac.id
}

\begin{abstract}
Our community service activity aimed at improving micro enterprise (ME) particularly led by woman in Kertasari Village, Taliwang Subdistrict, West Sumbawa District, West Nusa Tenggara. Warung Ibu Marna was selected in this activity because she did not have access to capital. We provided in-kind support for the capital in the form of pertamini machine and 100 liters gasoline with profit-sharing system. After the intervention, sale volume increased by $600 \%$ from 50 liters per week to 300 liters per week. This community service activity indicated that supporting capital through in-kind provision with profit sharing system with non-government organisation who worked for community empowerment has the potential to be alternative model for ME development. This system does not burden capital holder (e.g. due to non-performing loan) or $M E$ (e.g. paying loan and interest). This model is consistent with social capital perspective as the ME can perform well with trust between capital holder and $M E$.
\end{abstract}

Keywords: In-kind assistance, micro enterprise, NGO, profit-sharing system.

\begin{abstract}
Abstrak
Kegiatan pengabdian masyarakatyang kami lakukan bertujuan untuk mengembangkan usaha mikro khususnya bagi perempuan di Desa Kertasari, Kecamatan Taliwang, Kabupaten Sumbawa Barat, Nusa Tenggara Barat. Usaha mikro Warung Ibu Marna dipilih dalam kegiatan pengabdian masyarakat ini karena pelaku usaha tidak memiliki akses terhadap modal. Bentuk bantuan yang diterapkan yaitu penyediaan modal dalam bentuk in-kind (mesin pertamini dan bensin 100 liter) dengan sistem bagi hasil. Dampak dari bantuan yaitu meningkatnya volume penjualan Warung Ibu Marna meningkat sebesar 600\% dari 50 liter per minggu menjadi 300 liter per minggu. Pengabdian masyarakat ini mengindikasikan bahwa membantu permodalan dalam bentuk in-kind dengan pengembalian menggunakan sistem bagi hasil dapat menjadi alternatif model pengembangan usaha mikro bagi Lembaga Swadaya Masyarakat yang bergerak di bidang pemberdayaan masyarakat karena tidak membebani pemodal (misal karena kredit macet) maupun pelaku usaha (misal pembayaran kembali modal dan bunga). Model ini juga konsisten dengan perspektif sosial kapital dimana usaha mikro dapat berjalan dengan didasari kepercayaan antara pemodal dan pelaku usaha.
\end{abstract}

Kata kunci: Bantuan in-kind, LSM, sistem bagi hasil, usaha mikro.

\section{PENDAHULUAN}

Usaha Mikro, Kecil dan Menengah (UMKM) merupakan penggerak roda perekonomian yang signifikan di berbagai belahan dunia. Di Eropa, UMKM mencakup 99.8\% dari keseluruhan usaha pada tahun 2018, di mana sekitar 93\% dari UMKM merupakan usaha mikro (Muller et al., 2019). Di Indonesia, UMKM juga mendominasi proporsi jumlah unit usaha yaitu sekitar 99,8\% dengan usaha mikro sekitar 98.7\% (Masrifah et al., 2019; UkmIndonesia 2018). Pada tahun 2017, Usaha Mikro menyerap sekitar 107,2 juta tenaga kerja (89,2\%), Usaha Kecil 5,7 juta (4,74\%), dan Usaha Menengah 3,73 juta (3,11\%); sementara Usaha Besar menyerap sekitar 3,58 juta jiwa (Ukmindonesia, 2018).

Salah satu arah kebijakan dalam rangka peningkatan nilai tambah ekonomi pada tahun 2020 - 2024 sebagaimana tertuang dalam RPJMN 2020 - 2024 yaitu penguatan kewirausahaan dan usaha mikro, kecil dan mengengah (UMKM). Upaya-upaya afirmasi masih diperlukan khususnya untuk meningkatkan kapasitas dan nilai tambah usaha mikro, kecil dan menengah 
(UMKM). Hal ini penting mengingat UMKM mempekerjakan sekitar 97,0 persen tenaga kerja di Indonesia (Bappenas, 2019).

Terbatasnya lapangan pekerjaan merupakan masalah pokok ketenagakerjaan. Pada tahun 2018, Tingkat Pengangguran Terbuka (TPT) Kabupaten Sumbawa Barat berada pada kisaran 3,73 persen artinya dari 100 orang angkatan kerja di Kabupaten Sumbawa Barat ada sebanyak 3 sampai 4 orang yang merupakan pengangguran (BPS Kabupaten Sumbawa Barat 2018). Lapangan usaha Pertanian, Perkebunan, Kehutanan, Perburuan \& Perikanan menyerap tenaga kerja terbesar di Kabupaten Sumbawa Barat pada tahun 2018, yaitu mencapai 29,21\% dari keseluruhan tenaga kerja yang ada. Sektor berikutnya yang paling berkontribusi adalah Sektor Perdagangan Besar, Eceran, dan Reparasi mencapai 16,81 \%. Sektor pertambangan dan penggalian yang menjadi tumpuan dan mendominasi perekonomian Kabupaten Sumbawa Barat hanya mampu menyerap tenaga kerja sebesar 10,01\%.

Peran keberadaan UMKM yang paling menonjol adalah kemampuannya di dalam penyerapan tenaga kerja (mengurangi pengangguran) (Prasetyo, 2008). Oleh karena itu kegiatan pengabdian masyarakat yang kami lakukan bertujuan untuk mengembangkan usaha mikro khususnya bagi perempuan yang kesulitan mengakses kredit usaha rakyat di Desa Kertasari, Kecamatan Taliwang, Kabupaten Sumbawa Barat, Nusa Tenggara Barat. Kegiatan pengabdian ini mencoba untuk membuka jalan modal bagi pelaku usaha mikro melalui kerjasama dengan lembaga swadaya masyarakat lokal dengan sistem bagi hasil.

\section{METODE}

\section{Menentukan Penerima Manfaat}

Pada umumnya volume penjualan, besar modal dan besar aset digunakan untuk mendefinisikan UMKM. UU Nomor 20 Tahun 2008 tentang UMKM Pasal 1 angka 1 mendefinisikan usaha mikro sebagai usaha produktif milik orang atau perseorangan dan/atau badan usaha perseorangan yang mempunyai kriteria sebagai berikut: memiliki kekayaan yang paling banyak Rp. 50 juta (lima puluh juta rupiah) tidak termasuk tanah dan bangunan tempat usaha, atau memiliki hasil penjualan tahunan paling banyak Rp. 300 juta (tiga ratus juta rupiah). Beberapa negara dan ahli juga mendefinisikannya berdasarkan jumlah tenaga kerja. Batasan yang digunakan pada kegiatan pengabdian ini adalah jumlah tenaga kerja $<9$ orang, asset maksimal Rp. 50 juta dan omset tahunan paling banyak Rp. 300 juta.

Setelah melakukan observasi dan wawancara terhadap pelaku usaha mikro dari Desa Tepas, Desa Bree, Desa Jorok Tiram, dan Desa Kertasari, penulis memilih pelaku usaha mikro yaitu Warung Bu Marna di Desa Kertasari, Kecamatan Taliwang, Kabupaten Sumbawa Barat. Penulis memilih Desa Kertasari karena desa ini merupakan salah satu desa pesisir dan destinasi wisata yang mulai ramai dikunjungi sehingga banyak potensi pengembangan usaha mikro yang dapat dilakukan.

\section{Menentukan Bentuk Manfaat}

Kelemahan yang dihadapi oleh UMKM dalam meningkatkan kemampuan usaha sangat kompleks dan meliputi berbagai indikator yang saling terkait antara lain; kurangnya permodalan baik jumlah maupun sumbernya, kurangnya kemampuan manajerial dan keterampilan beroperasi dalam mengorganisir dan terbatasnya pemasaran (Suci et al., 2017). Hasil studi yang dilakukan oleh Masrifah et al., 2019 menunjukkan bahwa faktor yang paling menentukan keberhasilan upgrade usaha mikro yaitu literasi finansial dan pelatihan operasional.

Beberapa bentuk upaya peningkatan usaha mikro yang sudah banyak diterapkan antara lain: sistem pinjaman berbunga rendah (microfinance/loan), penyaluran bantuan in-kind, penguatan pemasaran, pelatihan-pelatihan dan pendampingan. Studi yang dilakukan oleh Fafchamps et al., (2014) di Ghana memberikan indikasi bahwa bantuan modal berupa uang tunai (cash) dan in-kind (peralatan) tidak memberikan profit/keuntungan bagi usaha mikro, namun 
bantuan in-kind menghasilkan profit bagi usaha lebih besar. Mereka menyimpulkan bahwa terdapat bukti sugestif bahwa perbedaan pada dampak dari pemberian bantuan tunai dan in-kind lebih berhubungan dengan kontrol diri dibandingkan dengan tekanan dari luar.

Di Indonesia, hasil beberapa wawancara yang dilakukan oleh penulis mengindikasikan bahwa bantuan in-kind berupa peralatan sering tidak sesuai dengan kebutuhan pelaku usaha mikro. Peralatan yang diberikan juga membutuhkan watt tinggi untuk pengoperasiannya sehingga pelaku usaha mikro tidak dapat menggunakan bantuan peralatan yang diberikan. Peralatan hanya menjadi aksesoris bahkan pada beberapa kasus, penerima bantuan lebih memilih untuk menjual alat bantuan tersebut.

Sementara itu, bantuan dalam bentuk pinjaman berbunga rendah juga dapat menghadapi kendala kredit macet, khususnya di lokasi pengabdian disebabkan karena bantuan pinjaman dianggap sebagai bantuan dana dari paslon yang didukung. Bank Indonesia (BI) mencatat, rasio kredit bermasalah (Non Performing Loan/NPL) di sektor Usaha Mikro, Kecil, dan Menengah (UMKM) secara nasional sebesar 3,79 persen di Januari 2019. Angka ini meningkat bila dibandingkan posisi per Desember 2018 yang tercatat sebesar 3,44 persen. Dari hasil wawancara dan studi literatur di atas, pada kegiatan pengabdian masyarakat ini, penulis memilih dua upaya penguatan usaha mikro yaitu penguatan modal melalui i) penyediaan alat dan bahan, kemudian pembagian keuntungan dilakukan melalui sistem bagi hasil dan (ii) bantuan spanduk nama warung untuk memudahkan calon konsumen menemukan warung.

\section{HASIL DAN PEMBAHASAN}

\section{Penerima Manfaat dan Bentuk Manfaat}

Usaha mikro kecil yang dilibatkan dalam kegiatan pengabdian masyarakat ini adalah Warung Ibu Marna. Sebagai pendatang, Ibu Marna dan suami tidak memiliki tanah yang dapat dikelola. Oleh karena itu, Ibu Marna mencoba usaha berjualan nasi campur dan bensin ecer di kios kecil yang disewa per bulan. Modal jualan diperoleh dari meminjam uang kepada keluarga. Ibu Marna belum pernah meminta bantuan kepada pemerintah karena untuk mengusulkan bantuan perlu membentuk kelompok yang terdiri dari minimal 10 orang.

Dari hasil diskusi dengan Ibu Marna, penulis menyimpulkan bahwa kendala dari usaha yang dijalankan oleh Ibu Marna adalah permodalan dan pemasaran. Dari permasalahan ini, penulis melakukan inovasi produk yaitu merubah sistem penjulan bensin premium yang awalnya menggunakan botol menjadi menggunakan mesin pertamini (mesin manual untuk menjual premium). Sistem kerjasama yang ditawarkan adalah sistem bagi hasil. Bantuan yang diberikan pada tahun 2017 dalam bentuk in-kind yaitu mesin pertamini (Gambar 1) dan persediaan bensin premium 100 liter. Ibu Marna dan suami hanya menjual persediaan premium dan membeli kembali ketika persediaan sudah habis. Kemudian keuntungan dari penjualan dikumpulkan. Diakhir bulan total keuntungan dibagi dengan pembagian 60\%-40\% (Ibu Marna 60\% dan Penulis 40\%). Selain itu, pada tanggal 1 Januari 2020, Komunitas Penjaga Pulau dan Komunitas Edu Arts memberikan bantuan kepada warung Ibu Marna berupa spanduk nama warung (Gambar 2). Hal ini kami pandang perlu agar warung mudah dikenal dan ditemukan oleh pembeli potensial sehingga dapat meningkatkan jumlah penjualan Warung Ibu Marna. 


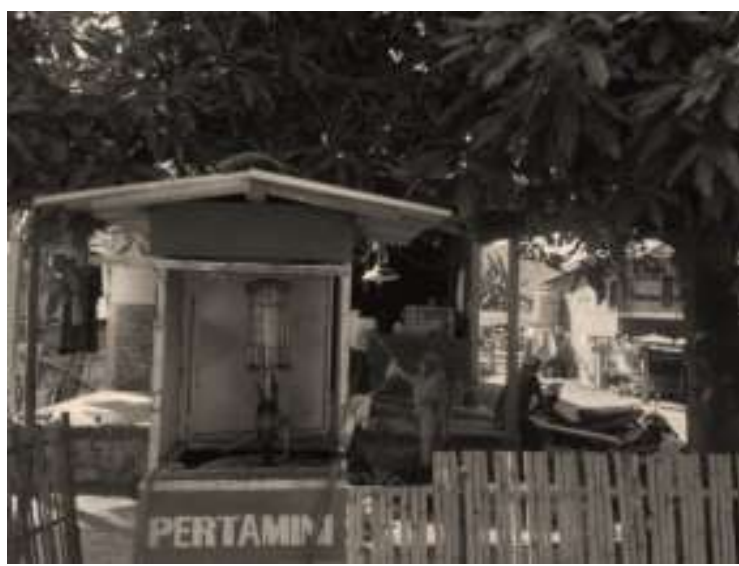

Gambar 1. Mesin pertamini (Dok. Penulis, 2019)

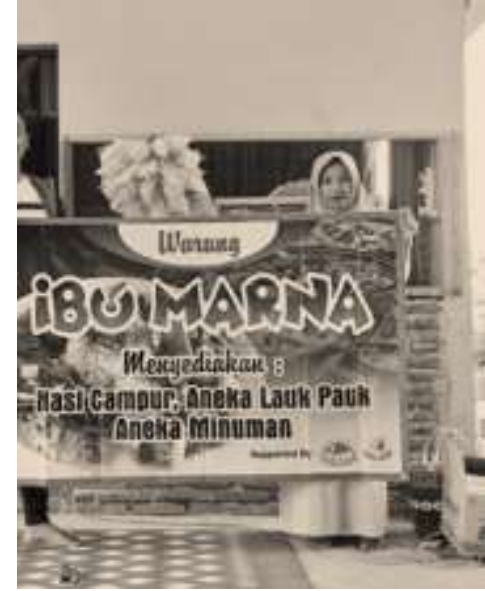

Gambar 2. Spanduk nama warung (Dok. Penulis, 2020)

\section{Dampak Bantuan}

Sebelum menggunakan mesin pertamini, Ibu Marna melakukan pengisian ulang 50 liter per minggu. Setelah menggunakan mesin pertamini, Ibu Marna melakukan pengisian ulang 300 liter per minggu. Jadi ada kenaikan omset penjualan sebesar $600 \%$ dari sebelum menggunakan mesin dengan setelah. Berikut laporan keuangan sederhana hasil penjualan pertamini.

Modal : : membeli premium 100 liter @Rp. 6.450. Total = Rp. 645.000,-

Penjualan : terjual premium 100 liter @ Rp. 8.000. Total = Rp. 800.000,-

Laba $\quad$ : laba per 100 liter $=$ Rp. 155.000 atau laba per liter sebesar Rp. 1550,-

Karena penjualan bisa mencapai 300 liter per minggu, maka laba per minggu adalah Rp. 465.000,-. Jika dikonversi ke per bulan, laba yang dihasilkan yaitu sekitar Rp. 1.860.000,-. Grafik Titik Impas tanpa sistem bagi hasil disajikan pada Gambar 3 berikut ini.

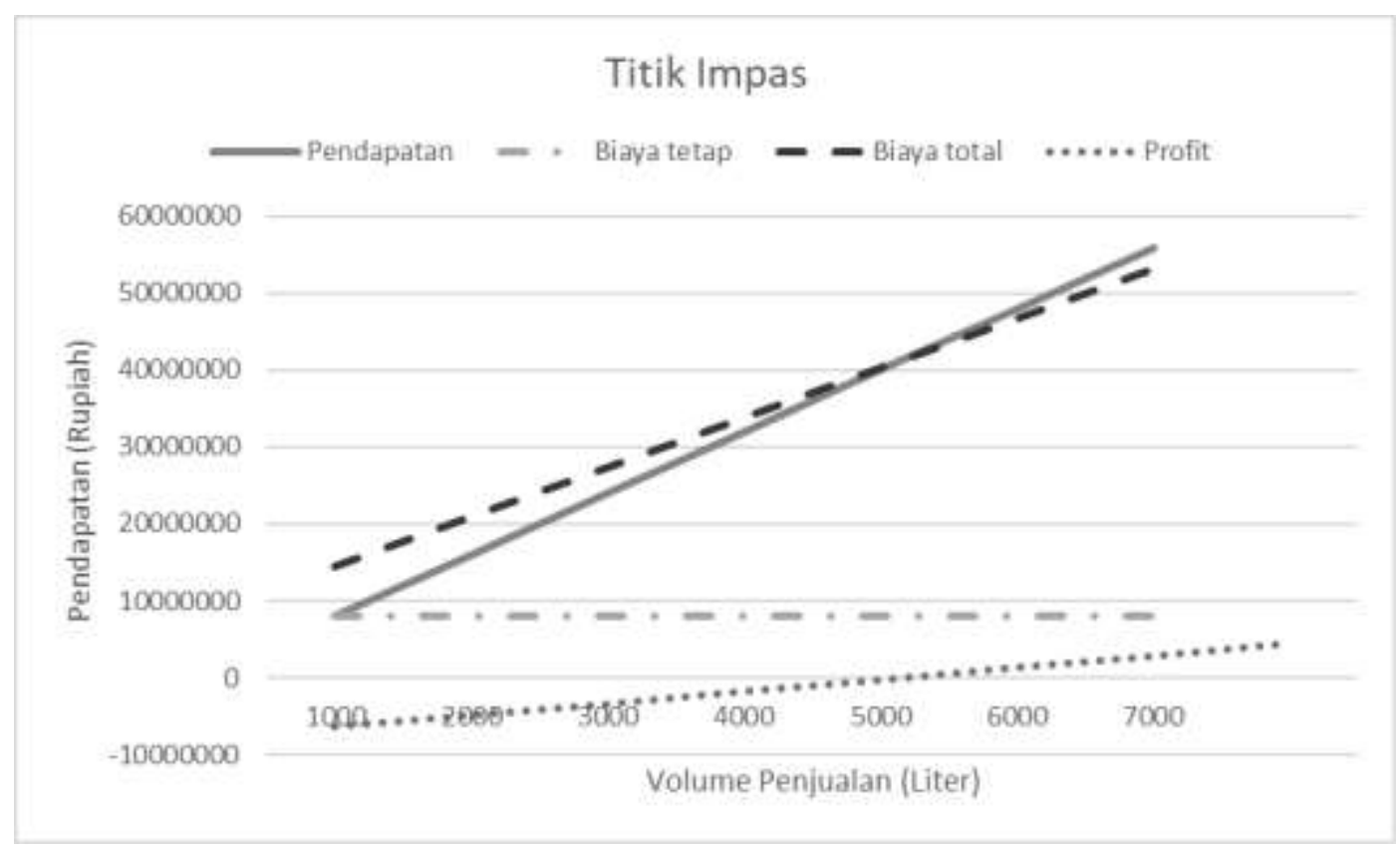

Gambar 3. Grafik Titik Impas 
Dari Grafik Titik Impas terlihat bahwa titik impas (break even point) jika laba tidak dibagi akan dicapai pada volume penjualan di atas 5000 (lima ribu) liter. Dari hasil perhitungan (Tabel 1), diperoleh titik impas unit sebesar 5161,29 liter. Karena dalam satu bulan, volume penjualan adalah sebesar 1200 liter, maka untuk mencapai BEP unit diperlukan waktu sekitar = $5161,29 / 1200=4.3$ bulan.

Tabel 1. Perhitungan Break Even Point (BEP) Unit

\begin{tabular}{lrr}
\hline & Unit & Total \\
\hline Unit terjual (liter per bulan) & 1200 & \\
Harga (Rupiah per liter) & 8000 & \\
$\begin{array}{l}\text { Pendapatan (Rupiah) } \\
\text { Biaya variable (per liter) }\end{array}$ & 6450 & 7740000 \\
$\begin{array}{l}\text { Profit per unit (per liter) } \\
\text { Biaya tetap }\end{array}$ & 1550 & \\
Break-even point unit (liter)** & & 8000000 \\
\hline
\end{tabular}

** Break even point adalah titik di mana total pendapatan sama dengan total biaya yang dikeluarkan (Garrison et al., 2011).

BEP = Biaya tetap / (Harga jual per unit - Biaya variabel per unit)

Sumber: Alnasser et al., 2014

Namun perlu diingat bahwa pemodal hanya memperoleh 40\% dari laba pada sistem bagi hasil ini, sisanya sebesar $60 \%$ diberikan kepada pelaku usaha mikro, sehingga diperoleh laba Rp. 1.116.000 untuk Ibu Marna dan Rp 744.000 untuk pemilik modal per bulan. Oleh karena itu, BEP unit bagi pemodal lebih lama dari grafik BEP tanpa bagi hasil seperti disampaikan di atas. Biaya investasi pertamini sekitar Rp. 8.000.000 dan biaya modal bensin premium awal sekitar Rp. $645.000,-$. Sehingga biaya total $=$ Rp. 8.645.000,-. Dengan profit bagi pemodal sebesar Rp.744.000 per bulan, maka biaya ini menjadi titik impas atau balik modal (break even point) bagi pemodal pada bulan ke 12. Dengan sistem bagi hasil pada kegiatan pengabdian ini, pelaku usaha mikro memperoleh pendapatan sebesar Rp. 1.116.000,- per bulan tanpa harus membayar cicilan.

Pada bulan Februari 2020 kami melakukan evaluasi kepada usaha mikro Warung Ibu Marna melalui wawancara. Adapun hasil yang kami peroleh adalah sebagai berikut:

1. Omset warung Ibu marna bertambah, sebelum adanya pertamini Ibu Marna hanya mampu menjual 50 liter perminggu premium. Setelah menggunakan mesin pertamini, ibu Marna mampu menjual 300 Liter premium per minggu.

2. Laba dari pembagian hasil pertamini ditabung untuk dijadikan modal tambahan menjual nasi campur dan lauk pauk, memenuhi kebutuhan sehari-hari, dan biaya pendidikan anak-anaknya.

3. Saat ini penjualan dari pertamini mulai berkurang karena banyaknya kompetitor. Pemilik modal mendapatkan laba sebesar sekitar Rp. 400.000,- per bulan, pelaku usaha mendapat laba sebesar sekitar Rp. 600.000,-. Namun laba bersih yang diperoleh oleh pelaku usaha pada tahun pertama dan ke dua sangat membantu pelaku untuk mengembangkan usaha lainnya yaitu usaha nasi campur. Pada tahun ke dua setelah bantuan in-kind diberikan, Ibu Marna mampu membeli sebidang tanah dan membangun rumah semi permanen yang juga digunakan menjadi tempat jualan yang lebih representatif. Ini menunjukkan bahwa pelaku usaha mampu mengelola keuangannya dengan baik.

4. Sekarang Ibu Marna tidak lagi pergi sendiri ke pasar baik untuk membeli keperluan warung maupun membeli persediaan premium, tetapi Ibu Marna bekerjasama dengan ojek lokal untuk pergi berbelanja ke kota. Hal ini sangat baik guna meningkatkan pendapatan masyarakat sekitar. 
5. Bantuan spanduk penanda warung yang diberikan oleh Komunitas Penjaga Pulau dan Edu Arts memberikan dampak yang baik bagi Warung Ibu Marna. Ibu Marna mengatakan: "Setelah ada nama warung, pembeli bisa dengan mudah menemukan warungnya dan setiap ada kegiatan desa selalu memesan lauk pauk di Warung Ibu Marna".

\section{Peran Modal Sosial}

Selain modal berupa barang/uang, modal sosial juga sangat penting dalam pertumbuhan usaha mikro. Studi yang dilakukan oleh Kwon \& Arenius (2010) menunjukkan bahwa konsisten dengan perspektif modal sosial, penduduk sebuah negara yang memiliki tingkat kepercayaan dan keanggotaan organisasi formal lebih tinggi akan memiliki persepsi lebih baik terhadap kesempatan berwirausaha.

Selain itu, hasil studi mereka juga menunjukkan bahwa penduduk sebuah negara dengan tingkat kepercayaan lebih tinggi juga akan lebih mungkin berinvestasi dan bekerjasama dengan pelaku usaha meskipun ikatan personalnya lemah (misal bukan keluarga , tidak satu organisasi, dll.). Dari kegiatan pengabdian ini, kepercayaan adalah salah satu faktor penting keberhasilan sistem bagi hasil antara pemodal dan pelaku usaha.

\section{Fase Pertumbuhan Usaha Mikro}

Lewis et al., 1983 membagi tahap perkembangan usaha kecil menjadi lima tahap yaitu (1) Existence; (2) Survival; (3) Success; (4) Take-off; (5) Resource Maturity. Berdasarkan tahapan tersebut, saat ini usaha Warung Ibu Marna sudah mencapai tahap 3 yaitu Sukses. Menurut penulis, dengan inovasi, usaha Warung Ibu Marna punya potensi untuk mencapai tahap 5 mengingat posisi warung yang strategis berada dekat dengan salah satu destinasi wisata di Kabupaten Sumbawa Barat. Inovasi bisa menjadi fokus pengabdian selanjutnya.

\section{KESIMPULAN}

Pengabdian masyarakat ini mengindikasikan bahwa membantu permodalan dalam bentuk in-kind dengan pengembalian menggunakan sistem bagi hasil dapat menjadi alternatif model pengembangan usaha mikro bagi Lembaga Swadaya Masyarakat yang bergerak di bidang pemberdayaan masyarakat karena tidak membebani pemodal (misal karena kredit macet) maupun pelaku usaha (misal pembayaran kembali modal dan bunga).

Sistem bagi hasil yang diterapkan antara LSM dengan pelaku usaha mikro dalam pengabdian ini mampu mengembangkan usaha mikro dengan modal sosial yang terpenting yaitu kepercayaan. Sistem ini berpotensi untuk diterapkan pada pelaku usaha yang benar-benar tidak memiliki akses ke sumber modal lain (misal kredit usaha rakyat yang memerlukan agunan, pinjaman di koperasi, dll.). Hasil dari kegiatan pengabdian ini mendukung hasil-hasil studi sebelumnya bahwa finansial literasi (Masrifah et al., 2019) dan kontrol diri (Fafchamps et al., 2014) berperan penting dalam keberhasilan pengembangan usaha mikro.

\section{UCAPAN TERIMA KASIH}

Penulis menyampaikan ucapan terima kasih kepada Komunitas Edu Arts atas kerja samanya.

\section{DAFTAR PUSTAKA}

Alnasser, Dr \& Shaban, Osama \& Al-Zubi, Ziad. (2014). The Effect of Using Break-Even-Point in Planning, Controlling, and Decision Making in the Industrial Jordanian Companies. International Journal of Academic Research in Business and Social Sciences. 4. 10.6007/IJARBSS/v4-i5/888.

Bappenas. (2019). Rancangan Teknokratik Rencana Pembangunan Jangka Menengah Nasional 2020 - 2024: Indonesia Berpenghasilan Menengah - Tinggi Yang Sejahtera, Adil, dan $\begin{array}{llll}\text { Berkesinambungan. Kementerian } & \text { BPN/313. }\end{array}$ 
https://doi.org/10.1017/CB09781107415324.004

Badan Statistik Kabupaten Sumbawa Barat (BPS Kabupaten Sumbawa Barat). (2020). Indeks Pembangunan Manusia Kabupaten Sumbawa Barat. Nomor Katalog: 4102002.5207.

Fafchamps, M., McKenzie, D., Quinn, S., \& Woodruff, C. (2014). Microenterprise growth and the flypaper effect: Evidence from a randomized experiment in Ghana. Journal of Development Economics, 106, 211-226. https://doi.org/https://doi.org/10.1016/j.jdeveco.2013.09.010

Garrison, Ray; Noreen, Eric; Brewer, Peter. (2011). "Managerial Accounting" 14th Ed. McGrawHill Irwin

Kwon, S. W., \& Arenius, P. (2010). Nations of entrepreneurs: A social capital perspective. Journal of Business Venturing. https://doi.org/10.1016/j.jbusvent.2008.10.008

Lewis, Virginia L. and Churchill, Neil C., The Five Stages of Small Business Growth (1983).

Harvard Business Review, Vol. 61, Issue 3, p. 30-50 1983. Available at SSRN: https://ssrn.com/abstract $=1504517$

Masrifah, A.R, Lahuri, S. B., Zarkasyi, M. R., and Untung, S. H. (2019). Micro Enterprise (MEs) Upgrading in Indonesia: Why MEs are not Growing? ICBLP 2019, February 13-14, Sidoarjo, Indonesia Copyright (C) 2019 EAI DOI 10.4108/eai.13-2-2019.2286205. https://eudl.eu/pdf/10.4108/eai.13-2-2019.2286205

Muller, P., Robin, N., Jessie, W., Schroder, J., Braun, H., Becker, L. S., Farrenkopf, J., Ruiz, F. A., Caboz, S., Ivanova, M., Lange, A., Lonkeu, O. K., Muhlshlegel, T. S., Pedersen, B., Privitera, M., Bomans, J., Bogen, E., \& Cooney, T. (2019). Annual Report on European SMEs 2018/2019 - Research \& Development and Innovation by SMEs. https://ec.europa.eu/docsroom/documents/38365/attachments/2/translations/en/rendit ions/native

Prasetyo, P. E. (2008). Peran Usaha Mikro Kecil dan Menengah (UMKM) dalam Kebijakan Penanggulangan Kemiskinan dan Pengangguran. Jurnal Akuntansi Dan Manajemen .

Suci, Y. R., Tinggi, S., \& Ekonomi, I. (2017). Perkembangan UMKM (Usaha Mikro Kecil Menengah) di Indonesia. Jurnal Ilmiah Fakultasi Ekonomi.

Ukmindonesia. (2018). Potret UMKM Indonesia Si Kecil yang Berperan Besar UKM Indonesia. Ukmindonesia.Id. 